\title{
TINDAK TUTUR ILOKUSI PADA POSTINGAN AKUN INSTAGRAM NKCTHI
}

\author{
Ayu Fitria Nurjanah', Fadilatun Khasanah², Galuh Mustikasari³, Haning \\ Intan Prastiwi ${ }^{4}$, Ita Cika Amalina ${ }^{5}$, Tita Eka Rusiarti6 \\ 1,2,3,4,5,6 Universitas Sebelas Maret \\ Email: ayufitria17759@gmail.com ${ }^{1}$
}

\begin{abstract}
Abstrak: Kegiatan bertindak tutur melibatkan interaksi antara penutur dan lawan tutur. Kajian ini membahas tentang tindak tutur ilokusi pada akun Instagram NKCTHI. Permasalahan yang dibahas meliputi bagaimana wujud tindak tutur ilokusi pada postingan akun Instagram NKCTHI. Maka, tujuan penelitian ini adalah untuk mendeskripsikan jenis tindak tutur ilokusi yang terdapat dalam postingan di akun NKCTHI dan menjelaskan konteks pada postingan di akun tersebut. Penelitian ini berjenis kualitatif deskriptif. Data penelitian ini berbentuk tuturan pada postingan akun instagram NKCTHI. Sumber data penelitian ini diambil dari akun Instagram NKCTHI. Data dianalisis dengan metode kontekstual. Hasil penelitian menunjukkan bahwa jenis tindak tutur yang terdapat dalam postingan akun Instagram NKCTHI meliputi (a) bentuk direktif dengan fungsi meminta dan fungsi bertanya; (b) bentuk asertif dengan fungsi menyatakan dan fungsi menyarankan; dan (c) bentuk ekspresif dengan fungsi meminta maaf dan fungsi berterima kasih. Kesimpulan penelitian ini adalah bahwa keberadaan tindak tutur dipengaruhi oleh adanya konteks atau maksud yang ingin disampaikan oleh penutur pada mitra tutur.
\end{abstract}

Kata Kunci: tindak tutur, ilokusi, instagram

\section{ILLOCUTIONARY SPEECH ACTS ON NKCTHI INSTAGRAM ACCOUNT POSTS}

\begin{abstract}
Speech act activities involve interaction between the speaker and the interlocutor This study discusses about illocutionary speech acts on the NKCTHI Instagram account. The issues discussed include how illocutionary speech acts form in the NKCTHI Instagram account posts. The purpose of this study is to describe the types of illocutionary speech acts contained on the NKCTHI Instagram account posts and explain the context of the posts on that account. This research is a descriptive qualitative type. This research data is in the form of a speech on the NKCTHI Instagram account post. The data source for this study was taken from the NKCTHI Instagram account. Data were analyzed using contextual methods. The results showed that the types of speech acts contained in the posts on the NKCTHI Instagram including (a) the form of a directive with an asking function and a questioning function; (b) an assertive form with a declared function and a suggesting function; and (c) the expressive form with apologize function and thank function. The conclusion of this study is that the existence of speech acts is influenced by the context or intent that the speaker wants to convey to the speech partner.
\end{abstract}

Keywords: speech act, illocution, instagram

\section{PENDAHULUAN}

Media sosial merupakan wadah yang ramai digunakan untuk berkomunikasi secara global antara penyampai informasi kepada penerima informasi. Salah satu media sosial yang

BASASTRA Jurnal Bahasa, Sastra, dan Pengajarannya

Volume 9 Nomor 2, Oktober 2021, P-ISSN 2302-6405, E-ISSN 2714-9765 
banyak digunakan, khususnya oleh anak muda adalah Instagram. Instagram merupakan salah satu media sosial yang banyak digunakan oleh orang-orang, khususnya kaum muda untuk berbagi informasi. Berdasarkan data statistik dari Hootsuite yang merupakan blog penyedia layanan media sosial, jumlah pengguna Instagram di seluruh dunia hingga bulan Januari tahun 2021 ini kurang lebih berjumlah satu miliar pengguna. Pada data tersebut, Indonesia menempati urutan keempat sebagai negara pengguna Instagram terbanyak dengan jumlah pengguna sekitar 78 juta pengguna.

Pengguna

Instagram menggunakan akun yang dimiliki untuk mengunggah banyak hal, seperti mengunggah aktivitas sehari-hari, membagikan informasi, hingga sekadar mengunggah kutipan kalimat yang memotivasi. Sebagai contohnya pada akun Instagram yang bernama @ nktchi atau Nanti Kita Cerita Tentang Hari Ini. Akun Instagram ini merupakan salah satu akun yang digemari oleh kaum muda dan memiliki jumlah pengikut lebih dari satu juta. Hal itu disebabkan karena akun tersebut mengunggah postingan yang berisi tentang segala sesuatu dalam kehidupan sehari-hari anak muda.

Pemilik akun memilih mengunggah kutipan kalimat sebagai bentuk tindakan yang menciptakan makna untuk pembaca. Tuturan-tuturan yang diunggah dalam postingan akun NKCTHI diolah oleh pemilik akun dengan bervariasi dan menarik, tetapi tetap berfokus pada topik kehidupan anak muda. Hal itu tidak terlepas dari adanya sebuah tindak tutur. Tindak tutur merupakan suatu hal penting yang terdapat dalam kajian ilmu pragmatik. Selain untuk mengujarkan suatu tuturan, seseorang juga dinilai melakukan tindakan seperti meminta, menyuruh, memengaruhi, dan lain sebagainya untuk dipahami oleh lawan tutur (Rustono, 1999:31).

Kegiatan bertindak tutur tersebut melibatkan interaksi antara penutur dan lawan tutur. Penutur merupakan orang yang memberikan tuturan secara lisan atau tertulis, sedangkan lawan tutur ialah yang memahami dan menjadi mitra tutur bagi penutur. Penutur dan lawan tutur dapat berupa penulis-pembaca atau pembicara-pendengar, baik yang berbentuk monolog maupun dialog.

Tindak tutur merupakan suatu tindakan (Yule, 2006:83). Tindak tutur tersebut terdiri atas tiga tindak yang saling terhubung. Pertama, tindak lokusi yang merupakan tindak dasar tuturan yang akan menciptakan ungkapan linguistik yang memiliki makna. Kedua, tindak ilokusi yang dipaparkan lewat penekanan komunikatif suatu tuturan. Ketiga, tindak perlokusi yakni menciptakan tuturan yang memiliki fungsi tanpa bermaksud memiliki akibat, tetapi memengaruhi lawan tuturnya.

Tindak tutur ilokusi dibagi menjadi lima, yaitu tindak tutur ilokusi direktif, asertif, ekspresif, komisif, dan

BASASTRA Jurnal Bahasa, Sastra, dan Pengajarannya 
deklaratif. Tindak tutur ini diklasifikasikan atas tujuan tuturannya. Tindak tutur direktif ialah tindak tutur yang memengaruhi lawan tutur untuk melakukan suatu tindakan, seperti meminta, memesan, bertanya. Asertif merupakan tindak tutur yang mendorong penutur pada kebenaran proporsi yang dituturkan, seperti menyatakan dan menyarankan. Ekspresif adalah tindak tutur yang mengungkapkan kondisi psikologis penutur, seperti meminta maaf, berterima kasih, dan mendoakan. Komisif ialah tindak tutur yang memengaruhi kondisi penutur untuk ke depannya, seperti berjanji. Lalu, deklaratif adalah tindak tutur yang menghubungkan tuturan dengan realitas yang terjadi di dunia nyata, seperti memvonis, menghukum, dan memecat.

Dalam penelitian ini, permasalahan penelitian yang akan dibahas adalah bagaimana wujud tindak tutur ilokusi yang terdapat dalam postingan akun instagram @NKCTHI dalam rentang postingan tahun 2019 hingga 2020. Tujuan dari penelitian ini adalah mendeskripsikan wujud tindak tutur ilokusi yang terdapat pada postingan akun Instagram NKCTHI.

Penulis tertarik untuk meneliti tindak tutur ilokusi pada postingan akun instagram NKCTHI karena sebelumnya belum pernah ada penelitian yang membahas mengenai hal tersebut. Penelitian relevan dengan objek tuturan yang bersumber dari postingan instagram sudah pernah dilakukan. Pertama, penelitian oleh Noviani (2020) mendeskripsikan mengenai jenis tindak tutur bahasa Indonesia secara umum, yakni perlokusi, lokusi, dan ilokusi dalam unggahan akun@halostiki. Penelitian tersebut juga membahas mengenai tindak tutur ilokusi, tetapi penelitian tersebut tidak membahas tindak tutur ilokusi secara khusus dan mendalam, tanpa adanya wujud dari masingmasing tindak tutur yang disebutkan. Kedua, penelitian oleh Pangesti (2019) hanya mengkaji jenis tindak tutur ilokusi ekspresif pada unggahan dan komentar akun@kampuszone sehingga jenis tindak tutur ilokusi yang lain tidak diuraikan. Ketiga, penelitian dilakukan oleh Azizah (2020) yang mendeskripsikan mengenai tindak tutur ilokusi pada tuturan caption akun instagram Ridwan Kamil, meliputi tindak tutur asertif, direktif, ekspresif, komisif, dan deklaratif. Sementara itu, dalam penelitian ini akan diuraikan tindak tutur ilokusi dalam akun Instagram NKCTHI secara lebih dalam dengan datanya berupa kutipan kalimat.

Berdasarkan latar belakang yang telah diuraikan, dapat disimpulkan bahwa fokus permasalahan yang akan dibahas adalah mengenai jenis tindak tutur ilokusi yang terdapat dalam postingan akun NKCTHI dan analisis konteks serta maksud dari postingan di akun tersebut. Maka, tujuan penelitian ini ialah untuk mendeskripsikan jenis 
tindak tutur ilokusi apa saja yang terdapat dalam postingan di akun NKCTHI dan menjelaskan konteks pada postingan di akun tersebut. Manfaat yang dapat diperoleh dari penelitian ini secara teoretis dapat memberikan wawasan baru dan menambah khazanah dalam penelitian linguistik. Sementara itu, manfaat praktis yang diperoleh ialah dapat memberikan pemahaman pada pengamat bahasa bahwa dalam postingan akun NKCTHI terdapat tindak tutur ilokusi dan penelitian ini dapat dijadikan sebagai bahan pertimbangan referensi terkait kajian pragmatik analisis tindak tutur.

\section{METODE}

Pada penelitian ini
menggunakan jenis penelitian
deskriptif kualitatif, yaitu dengan
mendeskripsikan tindak tutur pada postingan akun Instagram NKCTHI. Penelitian kualitatif adalah penelitian dimana peneliti ditempatkan sebagai instrumen kunci, teknik pengumpulan data dilakukan secara penggabungan dan analisis data bersifat induktif (Sugiyono, 2010: 9). Data yang digunakan dalam penelitian ini berbentuk monolog berupa kutipan mengenai kehidupan. Sumber data penelitian ini diambil dari akun instagram NKCTHI. Teknik pengumpulan data yang digunakan adalah teknik simak catat dengan menggunakan postingan yang diunggah di rentang tahun 2019 hingga 2020. Teknik simak ialah teknik memperoleh data dengan menyimak penggunaan bahasa dalam tuturan (Mahsun, 2005:242). Lalu, teknik catat adalah teknik pengumpulan data dengan mencatat hasil data yang telah disimak (Kesuma, 2007:45).

Pada penelitian ini, data dianalisis menggunakan metode kontekstual yang mengaitkan tuturan pada data penelitian dengan kontekskonteks yang ada (Rahardi, 2005:16). Kemudian, penyajian data dalam penelitian ini dilakukan dengan metode informal yang mana data disajikan dengan pernyataan atau ungkapan bahasa biasa. Data yang digunakan dipilih dengan beberapa kriteria di antaranya, terdiri dari postingan yang hanya terdiri dari satu slide, jumlah kalimat sedang yaitu 2-3 kalimat, dan postingan yang diunggah di rentang tahun 2019-2020.

\section{HASIL DAN PEMBAHASAN}

Berdasarkan analisis data, terdapat tiga jenis ilokusi yang muncul dalam Instagram NKCTHI. Ketiga jenis itu meliputi tindak tutur direktif, asertif, dan ekspresif. Tindak tutur direktif terwujud dalam maksud meminta, bertanya, menuntut, dan berpesan. Tindak tutur asertif terwujud dalam maksud menyatakan dan menyarankan. Tindak tutur ekspresif terwujud dalam maksud meminta maaf, berterima kasih, dan mendoakan. Berikut ini, disajikan Tabel 1 yang menunjukkan jumlah data yang dianalisis dan wujud ilokusi yang muncul dalam Instagram NKCTHI. 
Tabel 1. Wujud Tindak Tutur Ilokusi dalam Instagram NKCTHI

\begin{tabular}{clc}
\hline $\begin{array}{c}\text { Kategori } \\
\text { Tindak } \\
\text { Tutur }\end{array}$ & \multicolumn{1}{c}{ Maksud } & Jumlah \\
\hline \multirow{4}{*}{ Direktif } & - Meminta & 1 \\
& - Bertanya & 13 \\
& - Menuntut & 3 \\
& - Berpesan & 3 \\
\hline \multirow{2}{*}{ Asertif } & - Menyatakan & 15 \\
& - Menyarankan & 4 \\
\hline \multirow{2}{*}{ Ekspresif } & - Meminta maaf & 2 \\
& - Berterima kasih & 2 \\
& - Mendoakan & 7 \\
\hline & Total & 50 \\
\hline
\end{tabular}

Tindak Tutur Ilokusi Dalam Postingan Akun Instagram
NKCTHI

\section{Tindak Tutur Ilokusi Direktif}

Tindak tutur direktif merupakan bermaksud mempengaruhi mitra tutur untuk melakukan sesuatu. Tindak tutur jenis ini menunjukan harapan atau keinginan penutur sebagaimana ditunjukkan dalam data (1) - (6).

(1) "Bagi yang bisa, udah di rumah aja jangan ngeyel." (25 Maret 2020)

Konteks: Saat ini Indonesia tengah dilanda pandemi Covid-19. Oleh karena itu, sesuai anjuran pemerintah dalam rangka pencegahan penularan virus, Penutur bermaksud meminta pembaca untuk tetap di rumah saja. Agar tidak terkontaminasi Covid19.
Data (1) di atas termasuk dalam tindak tutur ilokusi direktif dengan maksud meminta. Hal tersebut ditunjukkan dengan adanya kata jangan ngeyel yang menunjukkan permintaan dan larangan pembaca agar tetap berada di rumah.

(2) "Apa pertanyaan yang sampai sekarang belum kamu temukan jawabannya?" (26 Mei 2020)

Konteks: Postingan tersebut masuk ke dalam tindak tutur direktif karena berupa kalimat pertanyaan. Dalam monolog tersebut, penulis bertanya pada pembacanya mengenai pertanyaan seperti apa yang belum ditemukan jawabannya.

Data (2) diklasifikasikan sebagai tindak tutur ilokusi direktif dengan maksud bertanya. Penulis memberikan pertanyaan pada pembaca dibuktikan dengan adanya kata tanya apa yang menandai tuturan tersebut.

(3) "Siapa yang mau dimenangkan, hubungannya atau egonya?" (13 Januari 2020)

Konteks: Situasi pada monolog tersebut ialah mengenai sebuah hubungan yang sedang kesulitan dan penulis membutuhkan kejelasan dari mitra tutur tentang keputusan yang akan diambil selanjutnya, yaitu hubungan atau ego.

Data (3) diklasifikasikan sebagai tindak tutur ilokusi dengan konteks tuturan bertanya. Hal tersebut dibuktikan dengan adanya kata tanya siapa yang merujuk pada sebuah 
pertanyaan yang membutuhkan jawaban dari lawan tutur atau pembaca.

(4) "Mundur selangkah menunggu sembuh atau maju saja sampai babak belur?" (8 Februari 2020)

Konteks: Dalam postingan tersebut terdapat situasi di mana penulis merasa sedang terluka. Lalu, penulis bertanya pada mitra tutur mengenai pilihan terbaik yang harus diambil.

Data (4) dinyatakan sebagai tindak tutur direktif berupa pertanyaan. Hal itu dikarenakan penulis memberikan dua pilihan bagi pembaca untuk menentukan hal terbaik yang dapat dilakukan dan dalam tuturan tersebut terdapat tanda baca tanya yang menunjukkan tindakan bertanya.

(5) "Apa kehilangan terakhir kamu?" (25 Juli 2020)

Konteks: Dalam tuturan tersebut, penulis atau penutur memberikan pertanyaan yang membutuhkan jawaban dari mitra tutur mengenai kehilangan terakhir yang membekas bagi pembaca. Kehilangan tersebut dapat berupa hal-hal berharga yang dimiliki oleh pembaca sehingga menjadi hal yang tidak terlupakan.

Data (5) termasuk tindak tutur ilokusi direktif yang berupa pertanyaan. Tindak tutur direktif dimaksudkan untuk memberikan pengaruh agar mitra tutur melakukan suatu tindakan. Tindak tutur direktif dalam postingan tersebut ditandai dengan adanya kata tanya apa dan tanda baca tanya. Penutur dalam postingan tersebut memberikan pertanyaan kepada mitra tutur dan tindakan yang diharapkan oleh penutur adalah adanya jawaban dari mitra tutur atas pertanyaan yang telah diajukan.

(6) "Duduk tenang, tanyakan sebentar, "hati ini maunya apa?" "langkah ini mau kemana?" dengarkan, jalankan." (16 Januari 2020)

Konteks: Penutur dalam postingan tersebut mencoba untuk membantu mitra tutur agar menjadi lebih tenang dan fokus untuk mencapai tujuan selanjutnya. Langkah untuk mencapai tujuan selanjutnya akan mudah diraih apabila mitra tutur menjalani dengan lebih tenang dan fokus.

Berdasarkan analisis, data (6) termasuk tindak tutur ilokusi direktif yang mempunyai maksud pemberian pertanyaan serta meminta. Tindak tutur ilokusi direktif dengan maksud pemberian pertanyaan dapat dilihat oleh adanya tanda baca tanya. Sementara itu, direktif dengan maksud meminta terdapat dalam penggalan kalimat terakhir yaitu dengarkan, jalankan. Penutur dalam postingan tersebut bertanya kepada mitra tutur tentang bagaimana kemauan hati serta langkah yang akan dipilih. Hal itu karena masih banyak orang-orang yang bingung memahami keinginan hati serta apa langkah terbaik yang akan diambil selanjutnya.

BASASTRA Jurnal Bahasa, Sastra, dan Pengajarannya

Volume 9 Nomor 2, Oktober 2021, P-ISSN 2302-6405, E-ISSN 2714-9765 


\section{Tindak Tutur Ilokusi Asertif}

Tindak tutur asertif merupakan tindak tutur yang memberikan dorongan terhadap penutur ke arah kebenaran proporsi yang ditunjukan, sehingga membawanya pada suatu nilai kebenaran. Pada dasarnya tindak tutur jenis ini mengungkapkan kepercayaan penutur. Tindak tutur tersebut ditunjukkan dalam data (1) - (8) berikut ini.

(1) "Lepaskan yang tidak mau dipertahankan." ( 29 November 2020)

Konteks: Penutur dalam postingan tersebut menyampaikan suatu pesan atau saran kepada mitra tutur yang dalam hal ini adalah kepada para pembaca untuk melepaskan seseorang yang tidak mau dipertahankan. Karena menjalin hubungan dengan seorang yang berlaku sesukanya, tidak dapat menghargai satu sama lain dalam hubungan, merupakan suatu hal yang sia-sia. Maka dari itulah, penutur menyarankan kepada para pembaca agar lebih baik melepaskan daripada harus bertahan kepada sesuatu yang memang pada dasarnya tidak berniat untuk menetap.

Data (1) termasuk tindak tutur ilokusi asertif yang mempunyai maksud menyarankan. Tindak tutur ini digunakan untuk memberikan dorongan terhadap penutur kearah kebenaran proporsi sehingga dapat membawa penutur pada suatu nilai kebenaran. Dalam postingan tersebut, penutur memberikan sebuah saran atau dorongan kepada mitra tutur untuk kesejahteraan hati dengan melepaskan seseorang yang tidak mau dipertahankan dalam suatu hubungan.

(2) "Semua usaha pada akhirnya tidak sia-sia. Karena sepenuhnya sudah diberikan dalam pertarungan. Tidak ada kalah untuk mereka yang menang lawan gelapnya diri sendiri." (30 Mei 2020)

Konteks: Dalam postingan tersebut, penulis memberikan pernyataan bahwa semua usaha yang dilakukan seseorang yang menang melawan keburukan dirinya sendiri itu tidak sia-sia. Hal tersebut dikarenakan seseorang tersebut berusaha secara maksimal untuk menjadi yang lebih baik lagi.

Data (2) termasuk tindak tutur ilokusi asertif yang berupa menyatakan. Tuturan yang digunakan dalam tindak tutur asertif berupa katakata yang sesuai dengan dunia yang diyakini dan dipercayai oleh penutur. Dalam postingan tersebut, penutur menyampaikan argumennya terkait suatu hal yang diyakini kebenarannya oleh penutur.

(3) "Rasanya level pembuktian tertinggi adalah saat tidak ada lagi rasa ingin membuktikan." (5 Juni 2020)

Konteks: Dari postingan tersebut, penulis menyatakan pemikirannya bahwa level tertinggi untuk membuktikan suatu hal itu saat seseorang tidak memiliki rasa ingin membuktikan lagi. Hal tersebut dapat dimungkinkan jika seseorang tersebut

BASASTRA Jurnal Bahasa, Sastra, dan Pengajarannya

Volume 9 Nomor 2, Oktober 2021, P-ISSN 2302-6405, E-ISSN 2714-9765 
sudah cukup merasa pembuktiannya diketahui oleh dirinya sendiri tanpa harus melibatkan orang lain untuk tahu.

Data (3) termasuk dalam tindak tutur ilokusi asertif karena dalam monolog tuturan tersebut penutur memberikan pernyataan. Hal tersebut dibuktikan dengan adanya kata adalah yang menunjukkan pernyataan mengenai suatu hal yang dalam konteks tuturan tersebut ialah level pembuktian.

(4) "Membagi kalimat jahat dan melakukan hal buruk kepada orang lain, tidak akan menyembuhkan." ( 24 Agustus 2020)

Konteks: Berdasarkan data pada postingan tersebut, penutur bermaksud menyampaikan argumennya bahwa melampiaskan kemarahan atas rasa sakit yang diterima bukan dengan cara melontarkan kalimat-kalimat jahat serta melakukan sesuatu hal yang buruk. Karena semua itu hanyalah siasia yang tidak dapat menyembuhkan luka yang kita alami. sebaliknya dapat menimbulkan masalah baru yang nantinya akan membuat kita menyesal. Langkah pertama yang harus kita lakukan adalah dengan menyembuhkan diri sendiri.

Data (4) merupakan tindak tutur ilokusi asertif karena dalam monolog tersebut menunjukkan adanya pernyataan atau penyampaian argumen penutur pada lawan tutur. Hal tersebut dapat diketahui apabila lawan tutur dapat mengetahui konteks tuturan yang dituliskan oleh penutur mengenai sikap buruk yang dinyatakan dalam data (4) tidak akan menimbulkan hal baik untuk siapa pun.

(5) "Kita masih terus belajar tentang menemukan dan melepaskan, memulai dan menyelesaikan, mencari dan menghilang, merawat dan merusak, memberi dan ..." (7 Juni 2020)

Konteks: Penutur mencoba menyampaikan bahwa hidup akan terus berjalan. Dalam perjalanan hidup, akan ada awal dan akhir dan akan terus ada baik dan buruk serta positif dan negatif. Hidup adalah tentang belajar tanpa selesai hingga menemui kematian.

Data (5) termasuk tindak tutur ilokusi asertif dengan fungsi menyampaikan sesuatu mengenai kehidupan yang terus berjalan, ditandai dengan pernyataan dari penutur kita masih terus belajar.

(6) "Silahkan patahkan jalannya... Menuju sana tidak cuma satu caranya." (19 Juni 2020)

Konteks: Penutur mencoba untuk meyakinkan mitra tutur bahwa bagaimanapun rintangan yang menghadang, jalan untuk mencapai tujuan tidak akan pernah habis. Walaupun diterjang kalimat jahat dari orang sekitar, tidak dapat menghalangi perjalanan hingga tujuan. Cara mencapai mimpi tidak hanya satu.

Data (6) termasuk tindak tutur ilokusi asertif dengan fungsi memberitahukan bahwa ada banyak jalan untuk menuju segalanya. Hal itu

BASASTRA Jurnal Bahasa, Sastra, dan Pengajarannya 
ditandai dengan tuturan, mепији sana tidak cuma satu caranya.

(7) 'Sebelum belajar 'membenci' coba mulai dengan 'mengenal',' (30 Mei 2020)

Konteks: Seringkali kita membenci seseorang tanpa suatu alasan. Membenci apa yang dia lakukan, membenci apa yang dia sukai, tanpa tahu alasan kenapa dia melakukan itu atau kenapa dia menyukai itu. Kita langsung menghakimi jika tindakan yang dia lakukan itu tidak cocok dengan kita dan patut untuk dibenci. Penutur dalam postingan itu menyarankan untuk pembaca supaya belajar mengenal sebelum membenci. Selaras dengan pepatah tak kenal maka tak sayang. benci menjadi solusi untuk yang tidak berusaha kenal dan paham. Tak kenal tapi kita benci dapat dikatakan sebagai hal yang nyeleneh. Cari alasan kenapa membenci dengan belajar mengenal.

Data (7) merupakan tindak tutur ilokusi asertif dengan fungsi menuntut. hal tersebut ditandai dengan tuturan penutur yang menuntut pembaca supaya belajar mengenal terlebih dahulu sebelum membenci orang lain. Hal tersebut ditunjukkan pada kata coba mengenal yang memiliki konteks agar mencoba mengenal sebelum membenci.

(8) "Bukan malang yang jadi musuh dari perjalanan, tapi malas dan menunda berjuang." (9 April 2019)

Konteks: Pada tuturan di atas, penutur bermaksud pernyataannya bahwa bukan malang yang menjadi musuh saat dalam perjalanan, tetapi sikap malas dan suka menunda-nunda. Orang yang suka menunda-nunda cenderung berpikir bahwa butuh waktu lama atau proses yang sangat panjang untuk menyelesaikan suatu pekerjaan. Belum tentu hal itu benar. Padahal mereka suka menunda pekerjaan yang seharusnya tidak memakan waktu lama. Kunci untuk mengalahkan sikap itu ialah dengan fokus. Pilih satu hal yang harus dilakukan cepat dan buat komitmen tenggat waktunya.

Data (8) merupakan tindak tutur asertif dengan fungsi menyatakan, hal tersebut ditandai dengan tuturan penutur yang menyatakan bahwa musuh dari perjalanan yang sebenarnya adalah rasa malas.

\section{Tindak Tutur Ilokusi Ekspresif}

Tindak ekspresif merupakan tindak tutur yang berfungsi untuk mengekspresikan atau mengungkapkan perasaan penutur terhadap keadaan yang tersirat dalam ilokusi. Tindak tutur tersebut ditunjukkan dalam data (1) - (6) berikut ini.

(1) "Maaf belum sempat langsung minta maaf." (23 Mei 2020)

Konteks: Postingan tersebut mengungkapkan sikap psikologis penutur terhadap suatu keadaan. Keadaan di sini ialah saat lebaran tahun lalu. Di mana lebaran tahun lalu kita dihadapkan dengan situasi yang mengharuskan kita membatasi kontak sosial yaitu tatap muka. Oleh karena itu

BASASTRA Jurnal Bahasa, Sastra, dan Pengajarannya 
penutur pun menyampaikan maaf untuk semua kesalahan dan kekhilafan yang pernah Penutur perbuat baik secara langsung atau tidak langsung. secara virtual karena belum sempat meminta maaf secara langsung.

Data (1) merupakan tindak tutur ekspresif dengan fungsi meminta maaf, hal tersebut ditandai dengan kata penutur yang meminta maaf karena belum sempat meminta maaf secara langsung.

(2) "Maaf Ibu belum semua harapmu terpenuhi, bukan karena aku tidak sayang. Kita sedang berjuang, mungkin belum sekarang." (12 Mei, 2019)

Konteks: Pada tuturan di atas yang berupa monolog, penutur menyampaikan permintaan maaf kepada ibunya, karena belum bisa memenuhi semua harapan ibunya. Semua yang diusahakan akan tercapai tetapi belum sekarang waktunya, mungkin yang akan datang, yang dilakukan saat ini adalah terus berjuang.

Data (2) merupakan tindak tutur ekspresif dengan fungsi meminta maaf, hal tersebut ditandai dengan penutur yang meminta maaf karena penutur belum dapat memenuhi keinginan ibunya.

\section{(3) "Terima kasih sudah bertahan.” (31 Juli 2019)}

Konteks: Pada tuturan di atas, penutur menyampaikan ucapan terima kasihnya kepada pembaca karena sudah bertahan dalam menjalani lika- liku yang ada di kehidupan. Dan jangan lupa untuk berterima kasih untuk diri kita sendiri yang sudah bertahan hidup hingga sejauh ini. Terima kasih karena sudah melangkahkan kaki sampai sejauh ini. Hidup memang terkadang terlalu sulit untuk dijalani. Masalah kerap datang silih berganti, tapi akan selalu ada pintu yang terbuka bila kita mau berusaha.

Data (3) termasuk tindak tutur ilokusi ekspresif dengan fungsi berterima kasih, ditandai dengan adanya kata terima kasih di awal kalimat, yaitu penutur menyampaikan terima kasih kepada pembaca karena sudah bertahan.

(4) "Terima kasih untuk temanteman yang baru beli buku NKCTHI. " (8 Januari 2019)

Konteks: Pada tuturan tersebut, penutur mengucapkan terima kasih pada pembaca yang telah membeli buku penutur yang berjudul NKCTHI (Nanti Kita Cerita Tentang Hari Ini). Terselip harapan dari penutur tentang pesan atau tulisan sederhana yang ada di buku membekas di hati pembaca.

Data (4) termasuk tindak tutur ilokusi ekspresif dengan fungsi berterima kasih, ditandai dengan adanya kata terima kasih pada awal kalimat, yaitu penulis buku NKCTHI mengucapkan terima kasih kepada orang-orang yang membeli buku NKCTHI karena telah membeli buku tersebut.

(5) "Semoga pesan sederhana yang saya kirim mendarat 
dengan selamat sampai ke hati kalian." (8 Januari 2019)

Konteks: Tuturan tersebut terdapat dalam situasi tutur penulis pada pembaca. Dalam tuturan tersebut penulis mengharapkan pesan-pesan yang ditulis dalam bukunya dapat dipahami dan dimaknai oleh pembaca.

Data (5) termasuk tindak tutur ilokusi ekspresi dengan fungsi mendoakan atau mengharapkan yang ditandai dengan adanya kata semoga di awal kalimat, di mana penulis pesan berdoa dan berharap jika pesan yang dikirimkannya dapat mendarat ke hati pembaca pesan.

(6) "Semoga banyak doa baik yang mendekat. Tepat, pada waktunya." (14 Februari 2020)

Konteks: Postingan tersebut memiliki konteks yang mana penutur mengharapkan agar orang-orang yang membaca tuturan tersebut mendapatkan doa baik yang sesuai dengan yang diinginkan.

Data (6) termasuk dalam tindak tutur ekspresif karena penutur mengharapkan atau berdoa agar mendapat doa baik yang akan diterimanya tepat pada waktunya. Hal tersebut dibuktikan dengan adanya kata semoga yang bermaksud tindakan ekspresif mengharapkan.

Berdasarkan penelitian, ditemukan tiga jenis tindak tutur ilokusi yang ada dalam akun Instagram NKCTHI, yaitu tindak tutur direktif, asertif, dan ekspresif. Hasil tersebut menunjukkan adanya perbedaan dengan beberapa penelitian sebelumnya. Dalam penelitian Noviani (2020), tindak tutur pada akun Instagram @halostiki membahas adanya tindak tutur lokusi, ilokusi, dan perlokusi. Lalu, dalam penelitian Pangesti (2019) hanya mengkaji tindak tutur ekspresif dalam akun Instagram @ kampuszone. Sementara itu, dalam penelitian Azizah (2020) pada akun Instagram Ridwan Kamil ditemukan tindak tutur ilokusi asertif, direktif, ekspresif, komisif, dan deklaratif.

Oleh karena itu, dapat disimpulkan bahwa keberadaan tindak tutur dipengaruhi oleh adanya konteks atau maksud yang ingin disampaikan oleh penutur pada mitra tutur. Hal tersebut dapat dilihat melalui hasil analisis data dalam akun NKCTHI menunjukkan beberapa perbedaan dengan penelitian sebelumnya. Akan tetapi, dari analisis data tersebut juga ditunjukkan bahwa penelitian ini mendukung adanya tindak tutur ilokusi yang ditemukan pada sebuah akun Instagram yang memiliki konteks atau maksud tertentu.

\section{SIMPULAN}

Berdasarkan analisis data yang telah dilakukan, wujud tindak tutur yang muncul dalam akun ini terdiri atas tindak tutur ilokusi direktif, asertif, dan ekspresif. Tindak tutur ilokusi direktif terwujud dalam tuturan yang memiliki fungsi bertanya, meminta, menuntut, dan berpesan. Tindak tutur ilokusi asertif terwujud dalam tuturan yang memiliki maksud menyatakan dan menyarankan. Lalu, tindak tutur ilokusi 
ekspresif terwujud dalam tindak tutur dengan maksud meminta maaf, berterima kasih, dan mendoakan.

Tindak tutur yang mendominasi dalam akun Instagram NKCTHI adalah tindak tutur asertif. Hal ini disebabkan karena postingan di akun NKCTHI berbentuk monolog sehingga maksud dari pemilik akun adalah menyampaikan atau menyatakan nasihat dan saran kepada pembacanya. Sementara itu, tindak tutur yang paling sedikit adalah tindak tutur ekspresif karena tuturan yang memiliki fungsi ekspresif dalam akun tersebut hanya ditemukan sedikit postingan.

\section{REFERENSI}

Azizah, I. M. (2019). Analisis Tindak Tutur Caption Dalam Instagram Ridwan Kamil. Jurnal Pendidikan Bahasa Dan Sastra Indonesia, 6(2), 229-42.

Anon. (2021). “@nkcthi • Foto Dan Video Instagram." Diakses 6 June 2021 dari https://www.instagram.com/nkcth i/

Astika, I. M. (2021). Analisis Tindak Tutur Ekspresif Dalam Acara Mata Najwa 'Perlawanan Mahasiswa. Jurnal Pendidikan Bahasa dan Sastra Indonesia. 6(1), 24-34.

Septi Tri, Wahyuni, dkk. (2018). Tindak Tutur Ilokusi Pada Caption Akun Islami Di Instagram. BASA TAKA 1. 5(2), 56-66.
George, Yule. (2006). Pragmatik. Yogyakarta: Pustaka Pelajar.

Pangesti, Indah Nurma. 2019. Tindak Tutur Ekspresif Di Akun Instagram @kampuszone. Jurnal Pendidikan Bahasa dan Sastra Indonesia. 4(2), 34-45.

Kesuma, T. M. (2007). Pengantar (Metode) Penelitian Bahasa. Yogyakarta: Carasvati Books.

Meirisa. (2017). Tindak Tutur Ilokusi

Dalam Interaksi Pembelajaran

Bahasa Indonesia (Kajian Etnografi Komunikasi di SMA Ehipassiko School BSD. Jurnal Pendidikan Dan Sastra: BAHTERA, 16(2), 57-66.

Muhammad. (2014). Metode Penelitian Bahasa. Yogyakarta: Ar-Ruzz Media.

Newberry, Christina.(2021). “44 Instagram Stats That Matter to Marketers in 2021." Retrieved (https://blog.hootsuite.com/instag ram-statistics).

Noviani, Ni Kadek Nita dkk. (2020). "Kajian Pragmatik Mengenai Tindak Tutur Bahasa Indonesia Dalam Unggahan Media Sosial Instagram @halostiki.” ALFABETA: Jurnal Bahasa, Sastra, Dan Pembelajarannya 3.

Nurulita, R.A.. (2013). Analisis Tindak Tutur Ilokusi dalam Dialog Film Animasi Meraih Mimpi. Skriptorium. 6(1), 67-78.

Rahardi, Kunjana. (2005). Pragmatik: Kesantunan Imperatif Bahasa Imperatif Bahasa Indonesia. Jakarta: Erlangga. 
Rohmadi, M. (2004). Pragmatik: Teori Dan Analisis. Yogyakarta: Lingkar Media.

Rustono. (1999). Pokok-Pokok Pragmatik. Semarang: CV IKIP Semarang Press.
Saifudin, Akhmad. (2019). Teori Tindak Tutur Dalam Studi Linguistik Pragmatik. LITE, 6(1), 34-45. 